\title{
Effect of Multicomponent Exercise and Nutrition Support on the Cognitive Function of Older Adults: A Randomized Controlled Trial
}

This article was published in the following Dove Press journal:

Clinical Interventions in Aging

\author{
Masakazu Imaoka iD ${ }^{1-4}$ \\ Hidetoshi Nakao ${ }^{1,2}$ \\ Misa Nakamura id ${ }^{1,2}$ \\ Fumie Tazaki ${ }^{1,2}$ \\ Motohiro Maebuchi ${ }^{5}$ \\ Masahisa lbuki ${ }^{5}$ \\ Masatoshi Takeda ${ }^{1,2}$ \\ 'Department of Rehabilitation, Osaka \\ Kawasaki Rehabilitation University, \\ Kaizuka, Osaka 597-0104, Japan; \\ ${ }^{2}$ Cognitive Reserve Research Center, \\ Kaizuka, Osaka 597-0I04, Japan; \\ ${ }^{3}$ Graduate School, Department of \\ Comprehensive Rehabilitation, Osaka \\ Prefecture University, Habikino, Osaka \\ 583-8555, Japan; ${ }^{4}$ Department of \\ Preventive Gerontology, National Center \\ for Geriatrics and Gerontology, Obu, \\ Aichi 474-85II, Japan; ${ }^{5}$ Planning \\ Department, R\&D Division, Fuji Oil Co., \\ Ltd., Izumisano, Osaka 598-8540, Japan
}

Correspondence: Masakazu Imaoka Department of Rehabilitation, Osaka Kawasaki Rehabilitation University, 158 Mizuma, Kaizuka, Osaka 597-0104, Japan $\mathrm{Tel} / \mathrm{Fax}+8 \mathrm{I}-72-446-6700$

Email imaokamasakazu@gmail.com
Purpose: This study compared the effects of a combination of soy peptide supplementation and exercise with those of exercise only, on the cognitive function of elderly adults.

Patients and methods: This randomized, non-blinded, controlled clinical trial included 67 participants aged 60 years or more with non-cognitive dysfunction who were divided into two groups according to the intervention method: an exercise group (Ex group, $n=36$ ) and an exercise plus nutrition group $(\mathrm{Ex}+\mathrm{Nt}$ group, $\mathrm{n}=31)$. The Ex group completed a memory training activity for 15 mins and aerobic exercise for 45 mins once a week for 90 days. The $\mathrm{Ex}+\mathrm{Nt}$ group completed the same training plus received soy peptide for 90 days. The MiniMental Status Examination score, trail-making test A/B score, skeletal muscle mass index, grip strength, gait speed, and geriatric depression scale were measured at baseline and post intervention. For comparison between the pretest and posttest measurements to determine the intervention effects, a two-way analysis of variance was performed. The significance level was set at $<5 \%$.

Results: A two-way analysis of variance revealed significant time effects on trail-making test-A score, skeletal muscle index, grip strength, and gait speed in both groups. There were significant time $\mathrm{x}$ group interactions for greater increase in calculation score.

Conclusion: A combination of exercise and soy peptide supplementation was effective in improving a portion of cognitive function.

Keywords: dementia, Alzheimer's disease, Mini-Mental Status Examination, soy peptide

\section{Introduction}

There has been a rapid increase in the prevalence of dementia owing to societal aging, and this poses a very serious problem. ${ }^{1}$ According to the World Alzheimer's Association, the proportion of people with dementia is increasing at a rate of one person every 3 seconds. This value is likely to reach 74.7 million people worldwide in 2030, accompanied by increasing medical and nursing care expenses, at an estimated cost of 818 billion USD. ${ }^{2}$ Risk factors for dementia include the presence of the apoE4 protein, ${ }^{3}$ high blood pressure, ${ }^{4-6}$ diabetes, ${ }^{7}$ lipid abnormality, ${ }^{8}$ depression, ${ }^{9}$ inactivity, ${ }^{10}$ low income, ${ }^{11,12}$ and a decrease in the frequency of interpersonal exchanges. ${ }^{13}$ Conversely, protective factors include the presence of higher education, ${ }^{14}$ physical activity, ${ }^{15}$ participation in cognitive activities, ${ }^{15}$ antioxidant food intake, ${ }^{16,17}$ moderate alcohol consumption, ${ }^{18}$ and increased frequency of social participation and interpersonal exchanges. ${ }^{19}$ Since effective drugs for this disease have not yet been developed, it is important to reduce the number of risk 
factors through lifestyle modifications to include as many protective factors as possible.

According to previous studies, ${ }^{20}$ the risk of dementia is halved in people who exercise more than three times a week, compared to the risk in those without exercise habits. Amyloid $\beta$ can start accumulating in the brain more than 20 years before the onset of Alzheimer-type dementia, and exercise is known to prevent this type of accumulation. ${ }^{21}$ Previous studies have shown that the maintenance of strong motor function can help reduce future risk of dementia at older age. ${ }^{22}$ One previous study has suggested that the promotion of brain derived neurotrophic factor (BDNF) expression due to exercising inhibits cognitive decline. ${ }^{23}$

In terms of nutrition, recent studies have demonstrated the properties of certain food components that might potentially prevent cognitive impairment and dementia. ${ }^{17}$ Among them, we focused on soy peptide, which is obtained by hydrolyzing soy protein isolate (SPI) with food processing enzymes. Soy peptide is classified as a functional food with diverse physiological functions attributed in the form of bioactive peptides that are rapidly absorbed from the small intestine. ${ }^{24}$ One study demonstrated that daily supplementation with soy peptide improved cognitive abilities, including sustained attention and short- and long-term memory in healthy middle-aged and elderly adults. ${ }^{25}$ In addition, the oral administration of soy peptide for 6 months has been reported to suppress age-related cognitive decline and result in an upregulation of BDNF expression in senescenceaccelerated mouse brains. ${ }^{26}$

However, to our knowledge, the effect of a combination of exercise and soy peptide intake on cognitive function has not yet been investigated. To this aim, we compared the effects of an exercise program including cognitive training in combination with soy peptide intake and those of the exercise program alone on the cognitive function of community-dwelling older individuals.

\section{Materials and Methods}

\section{Trial Design and Participants}

This non-blind randomized controlled trial (RCT) compared the effects of a multicomponent exercise program (multiple forms of exercise combined with songs and cognitive training) supplemented with soy protein on cognitive function in elderly adults with the effects of the exercise program alone. The Ethics Committee of the Osaka Kawasaki Rehabilitation University (Reference
No. OKRU29-A021) approved the trial protocol and the trial was registered at the University Hospital Medical Information Network Clinical Trials Registry (UMIN000030404). Written informed consent for study participation was obtained from all the participants in accordance with the tenets of the Declaration of Helsinki, and no stipend was provided.

Participants included community-dwelling elderly adults living in Osaka, Japan. People aged 60 years or older who could independently perform the activities of daily living were enrolled. Those with collagen disease, depression, a history of cardiovascular disease, medical contraindications to exercise, and Parkinson's disease were excluded. Using a computerized 1:1 randomization scheme, the eligible participants $(n=74)$ were assigned to the exercise $(E x)(n=37)$ or the exercise plus nutrition $(E x$ $+\mathrm{Nt})$ groups $(\mathrm{n}=37)$.

\section{Interventions}

\section{Multicomponent Exercise}

Multicomponent exercise sessions were conducted at the Kaizuka City Welfare Center. Participants engaged in a 15-min memory training and 45-min aerobic exercise session once a week for 3 months. As part of the memory training, participants were required to listen to a novel story and repeat its contents, and perform the dual tasks of clapping their hands in multiples of three and five while stepping on the spot. The aerobic exercise session included self-stretching for $10 \mathrm{~min}$, followed by an aerobic exercise regimen of $15 \mathrm{~min}$. This was followed by conditioning for 10 min such that the heart rate normalized. The aerobic exercise regimen included gymnastics using songs featuring the locally popular character "Tsugasan." Gymnastics were practiced on yoga mats $(60 \mathrm{~cm} \times 173 \mathrm{~cm})$. The regimen included lower-limb steps, rhythmic exercises of the upper limbs, and deft movement of the fingers. Finally, mindfulness exercises were performed in the recumbent position for $10 \mathrm{~min}$. All exercises were taught by two physical therapists and several staff volunteers.

\section{Nutrition}

A commercial drink (Peptide Athleeta 4000, Fuji Oil Co., Osaka, Japan) was used for soy peptide supplementation. Table 1 shows the nutrition facts label of Peptide Athleeta 4000. The net weight of Peptide Athleeta 4000 that contains $4 \mathrm{~g}$ soy peptide was $190 \mathrm{~g}$. 
Table I Nutrition Facts Label of Peptide Athleeta 4000

\begin{tabular}{|l|l|}
\hline Total calories (kcal) & 48 \\
Protein $(\mathrm{g})$ & 4.4 \\
Fat $(\mathrm{g})$ & 0 \\
Carbohydrate $(\mathrm{g})$ & 8.9 \\
Sodium (mg) & 112 \\
Valine (mg) & 184 \\
Leucine (mg) & 300 \\
Isoleucine (mg) & 177 \\
Soy peptide (mg) & 4000 \\
\hline
\end{tabular}

\section{Cognitive Status Measures}

The Japanese language version of the Mini-Mental State Examination (MMSE) is widely used for the evaluation of cognitive function and cognitive impairment screening. ${ }^{27}$ The MMSE score ranges from 0 to 30, with lower scores representing weaker cognitive function.

The trail making test (TMT) — a well-known psychomotor test ${ }^{28}$ - was used to evaluate attentiveness. In Part A of the TMT, participants are instructed to draw lines to connect 25 encircled numbers distributed on a page. Part $\mathrm{B}$ of TMT is completed by alternately linking the sequential numbers and letters on a page. This provides information on an individual's cognitive flexibility. ${ }^{29}$

\section{Assessment of Body Composition}

Physiological parameters measured using bioelectrical impedance analysis (InBody270; InBody, Tokyo, Japan) with 20 and $1000 \mathrm{kHz}$ frequencies were obtained from the participants' electronic medical records. ${ }^{30}$ Participants were instructed to grasp the handles of the analyzer and stand on electrodes contacting the lower surface of their feet while they were wearing normal indoor clothing without socks or shoes. The surface of the hand electrode was placed in contact with each of the five fingers, while the participants' heels and forefoot were placed on the circular foot electrode. Measurements were recorded within $30 \mathrm{sec}$ by the staff. Participants were required to fast and avoid vigorous exercise for at least one hour before the assessment. Body mass index (BMI) was calculated by dividing the body weight $(\mathrm{kg})$ by height squared $\left(\mathrm{m}^{2}\right)$. The appendicular skeletal muscle index (SMI) was derived from the appendicular muscle mass $(\mathrm{kg})$ divided by height squared $\left(\mathrm{m}^{2}\right)$.

\section{Muscle Strength}

Handgrip strength is a well-known measure of muscle strength and is significantly associated with whole-body muscle strength. ${ }^{31}$ The maximum voluntary isometric strength of the handgrip was measured with the dominant hand while in a standing position, by means of a hand dynamometer GripD (Takei, Niigata, Japan). Other bodily movements were not permitted.

\section{Gait Speed}

Participants were instructed to walk $6.4 \mathrm{~m}$ (divided into two 2.0-m zones at each end and a 2.4-m middle-zone) at a speed they found comfortable. ${ }^{32}$ The time needed (in sec) to pass the 2.4-m middle zone was measured for the calculation of gait speed $(\mathrm{m} / \mathrm{s})$. Participants could use a cane or walker if they were unable to perform the gait test independently. An average of five gait tests was used for evaluation.

\section{Geriatric Depression Scale 15}

The Japanese version of the Geriatric Depression Scale 15 $(\text { GDS-15) })^{33}$ is a self-report evaluation. The scale comprises 15 items: 10 items confirm depression if the answers are positive, while the remaining 5 items confirm depression if the answers are negative. Normal scores range from $0-4$, depending on factors such as age, education, and complaints; a score of 5-8 indicates mild depression, 9-11 moderate depression, and 12-15 severe depression. In this study, GDS-15 was measured with permission from the copyright holder.

\section{Sample Size}

To determine the sample size required for the detection of a significant interaction effect between intervention and time (pre/post), we performed a power calculation using the following parameters: a moderate effect size $(\mathrm{f}=0.25), \alpha$ error $=0.05, \beta$ error $=0.20$. The required number of cases was 33 in each group. We estimated a $10 \%$ dropout rate, bringing the target number of participants to 37 per group.

\section{Statistical Analyses}

Analysis of variance was used for within- and betweengroup comparisons of continuous variables and a chisquare test was used for between-group comparisons of categorical variables at baseline. In addition, the effect of each intervention on outcome measurements was analyzed using a mixed $2 \times 2$ group $(\mathrm{Ex}, \mathrm{Ex}+\mathrm{Nt}$ group $) \times$ time $($ pre, post) two-way analysis of variance (ANOVA).

In the sub-analysis, the sub-items of the MMSEorientation time, orientation place, registration, attention and calculation, recall and language, and praxis - were analyzed separately in the Ex and Ex+Nt group using twoway ANOVA. All statistical analyses were performed 


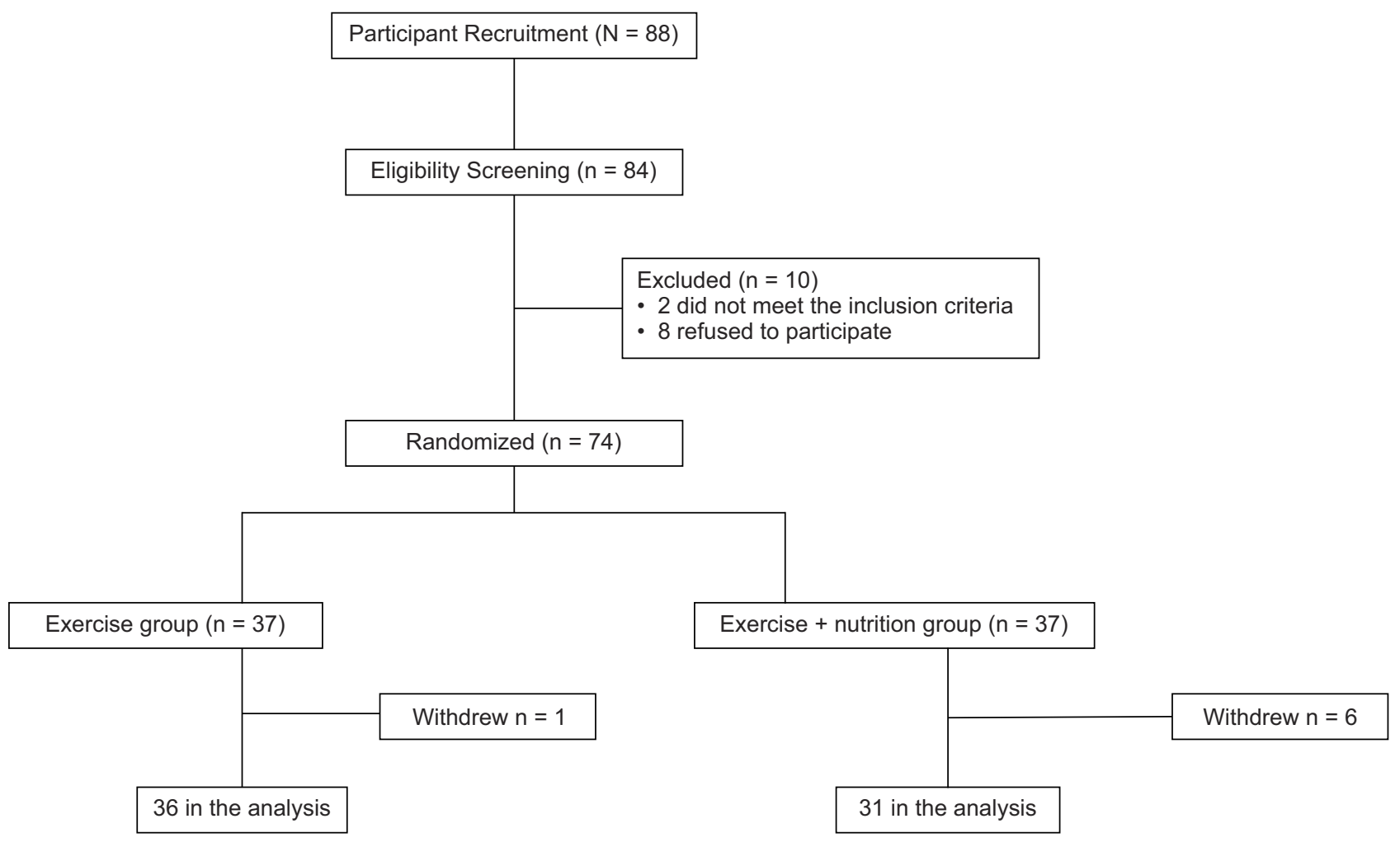

Figure I A flowchart showing the distribution of participants the trial.

using IBM SPSS Statistics for Windows, Version 25.0 (IBM Corp., Armonk, New York). P $<0.05$ was considered to be statistically significant.

\section{Results}

Of the 74 individuals selected for the study, 67 (76.1\%) completed the 3-month follow-up (Figure 1; Ex group: 36 [97.3\%] and Ex + Nt group: 31 [83.8\%]). The baseline characteristics of the participants were matched and found to be comparable (Table 2). The median relative adherence rate was $90 \%$ with nutritional supplementation. No health problems, musculoskeletal complications, muscle pain, or fall incidents occurred during the study period.

Table 3 presents a comparison of the cognitive function and physical function test values before and after the intervention. The pre- and post-intervention group statistics and group-time interactions are shown in Table 3. Significant time-specific effects were observed for TMTA, gait speed, grip strength, and SMI.

Table 4 presents the results of comparisons of MMSE total and subdivision changes in the Exercise and Exercise + Nutrition groups. There was a statistically significant interaction between time and group $(\mathrm{p}<0.05)$.

Table 2 Baseline Characteristics of the Participants in the Two Groups

\begin{tabular}{|l|l|l|l|l|l|l|l|l|l|l|l|}
\hline & \multicolumn{3}{l}{ Overall $\mathbf{n = 7 4}$} & \multicolumn{3}{l|}{ Exercise + Nutrition n=37 } & \multicolumn{2}{l|}{ Exercise $\mathbf{n = 3 7}$} & F-Value & \multirow{2}{*}{ P-Value } \\
\cline { 2 - 11 } & Mean & & SD & Mean & & SD & Mean & & SD & \\
\hline Age & 75.2 & \pm & 5.5 & 74.4 & \pm & 5.6 & 76.3 & \pm & 5.4 & 0.112 & 0.216 \\
Height, cm & 152.1 & \pm & 7.3 & 152.4 & \pm & 7.7 & 151.8 & \pm & 7.0 & 0.754 & 0.725 \\
Weight, $\mathrm{kg}$ & 53.8 & \pm & 9.4 & 53.1 & \pm & 9.2 & 54.5 & \pm & 9.5 & 0.513 & 0.514 \\
BMI, kg/m & 23.2 & \pm & 3.1 & 22.8 & \pm & 2.9 & 23.6 & \pm & 3.2 & 0.360 & 0.273 \\
\hline Women, $\mathrm{n} \%$ & 61 & $82.4 \%$ & 31 & $83.8 \%$ & & 30 & $81.1 \%$ & & 0.760 \\
\hline
\end{tabular}

Abbreviation: BMI, body mass index. 
Table 3 Comparisons of Changes in Exercise and Exercise + Nutrition Groups

\begin{tabular}{|c|c|c|c|c|c|c|c|c|c|c|}
\hline & \multicolumn{3}{|l|}{ Pre } & \multicolumn{3}{|l|}{ Post } & \multicolumn{4}{|c|}{ Two-Way ANOVA } \\
\hline & \multirow[b]{3}{*}{ Mean } & & \multirow[b]{3}{*}{ SD } & \multirow[b]{3}{*}{ Mean } & & \multirow[b]{3}{*}{ SD } & \multicolumn{2}{|c|}{ Time Effect } & \multirow{2}{*}{\multicolumn{2}{|c|}{$\frac{\text { Time } \times \text { Group }}{\text { Interaction }}$}} \\
\hline & & & & & & & \multirow[b]{2}{*}{ F-Value } & \multirow[b]{2}{*}{ P-Value } & & \\
\hline & & & & & & & & & F-Value & P-Value \\
\hline \multirow{3}{*}{$\begin{array}{l}\text { MMSE } \\
\text { Exercise + Nutrition } \\
\text { Exercise }\end{array}$} & & & & & & & \multirow{3}{*}{0.93} & \multirow{3}{*}{0.339} & \multirow{3}{*}{1.66} & \multirow{3}{*}{0.20} \\
\hline & 28.3 & \pm & 1.8 & 28.8 & \pm & 1.4 & & & & \\
\hline & 28.2 & \pm & 2.6 & 28.1 & \pm & 2.7 & & & & \\
\hline \multirow{3}{*}{$\begin{array}{l}\text { TMT-A } \\
\text { Exercise + Nutrition } \\
\text { Exercise }\end{array}$} & & & & & & & \multirow{3}{*}{15.65} & \multirow{3}{*}{$<0.05^{*}$} & \multirow{3}{*}{0.04} & \multirow{3}{*}{0.85} \\
\hline & 98.4 & \pm & 26.4 & 88.1 & \pm & 22.9 & & & & \\
\hline & 107.8 & \pm & 33.8 & 96.4 & \pm & 34.1 & & & & \\
\hline \multicolumn{11}{|l|}{ TMT-B } \\
\hline Exercise + Nutrition & 142.2 & \pm & 74.3 & 146.6 & \pm & 47.3 & \multirow[t]{2}{*}{0.10} & \multirow[t]{2}{*}{0.75} & \multirow[t]{2}{*}{0.86} & \multirow[t]{2}{*}{0.36} \\
\hline Exercise & 150.4 & \pm & 71.0 & $|4| .4$ & \pm & 67.7 & & & & \\
\hline \multicolumn{11}{|l|}{ Gait speed } \\
\hline Exercise + Nutrition & 1.24 & \pm & 0.2 & 1.32 & \pm & 0.2 & \multirow[t]{2}{*}{32.84} & \multirow[t]{2}{*}{$<0.05^{*}$} & 2.37 & 0.13 \\
\hline Exercise & 1.17 & \pm & 0.2 & 1.30 & \pm & 0.2 & & & & \\
\hline Grip strength & & & & & & & & & & \\
\hline Exercise + Nutrition & 21.7 & \pm & 5.7 & 24.0 & \pm & 5.0 & 56.28 & $<0.05^{*}$ & 0.27 & 0.61 \\
\hline Exercise & 21.8 & \pm & 6.8 & 24.4 & \pm & 6.6 & & & & \\
\hline SMI & & & & & & & & & & \\
\hline Exercise + Nutrition & 5.76 & \pm & 0.8 & 5.87 & \pm & 0.9 & 8.90 & $<0.05^{*}$ & 0.00 & 0.9 \\
\hline Exercise & 5.89 & \pm & 0.9 & 5.99 & \pm & 0.9 & & & & \\
\hline GDS & & & & & & & & & & \\
\hline Exercise + Nutrition & 3.52 & \pm & 2.4 & 3.16 & \pm & 2.7 & 0.11 & 0.74 & 0.59 & 0.44 \\
\hline Exercise & 3.89 & \pm & 2.7 & 4.03 & \pm & 2.5 & & & & \\
\hline
\end{tabular}

Note: $* \mathrm{p}<0.05$

Abbreviations: MMSE, Mini-Mental State Examination; TMT, Trail Making Test; SMI, Skeletal mass index; GDS, Geriatric Depression Scale; SD, standard deviation.

\section{Discussion}

There is no absolute method to prevent dementia. However, a healthy lifestyle that includes regular physical activity, cognitive activities, and a well-balanced diet reduces the risk of dementia. ${ }^{34}$ Conventional exercise programs, such as those involving walking, have shown cognitive benefits in community-dwelling elderly people. ${ }^{35}$ However, the beneficial effects of exercise cannot be experienced without continued participation. ${ }^{36}$ In this study, therefore, we designed a multicomponent exercise program using songs featuring a locally popular character with cooperation from the local government to ensure a high rate of participation (final participation rate: $76.1 \%$ ). Moreover, the program included a memory training session for the prevention of dementia. The 3-month multicomponent exercise intervention had beneficial effects on physiological function such as gait speed, grip strength, and on SMIin community-dwelling older adults.
In addition, 3-month multicomponent exercise intervention improved cognitive function as evidenced by the improved TMT-A, but not TMT-B. This result is consistent with those of a previous dance intervention study targeting mild cognitive impairment, in that the TMT-A score improved while the TMT-B score did not. ${ }^{37}$ These results suggest a selective beneficial effect of exercise on cognitive function.

Soy peptide is generated by the enzymatic digestion of SPI. SPI has a Protein Digestibility Corrected Amino Acid Score of 1.0, the highest possible score. ${ }^{38}$ This means that soy peptide derived from SPI has the ideal amino acid balance. Soy peptide ingestion can maintain and promote the synthesis and metabolism of noradrenaline in the brain. ${ }^{39}$ Several studies have reported an alleviation of peripheral fatigue following its rapid absorption. ${ }^{24} \mathrm{~A}$ recent clinical study also demonstrated the positive effects of soy peptide on brain function. ${ }^{40-42}$ Furthermore, another study showed 
Table 4 Comparisons of MMSE Total and Subdivision Changes in Exercise and Exercise + Nutrition Groups

\begin{tabular}{|c|c|c|c|c|c|c|c|c|c|c|}
\hline & \multicolumn{3}{|l|}{ Pre } & \multicolumn{3}{|l|}{ Post } & \multicolumn{4}{|c|}{ Two-Way ANOVA } \\
\hline & \multirow[b]{3}{*}{ Mean } & & \multirow[b]{3}{*}{ SD } & \multirow[b]{3}{*}{ Mean } & & \multirow[b]{3}{*}{ SD } & \multicolumn{2}{|c|}{ Time Effect } & \multirow{2}{*}{\multicolumn{2}{|c|}{$\begin{array}{l}\text { Time } \times \text { Group } \\
\text { Interaction }\end{array}$}} \\
\hline & & & & & & & & & & \\
\hline & & & & & & & F-Value & P-Value & F-Value & P-Value \\
\hline $\begin{array}{l}\text { Orientation Time } \\
\text { Exercise + Nutrition } \\
\text { Exercise }\end{array}$ & $\begin{array}{l}4.81 \\
4.89\end{array}$ & $\begin{array}{l} \pm \\
\pm\end{array}$ & $\begin{array}{l}0.5 \\
0.4\end{array}$ & $\begin{array}{l}4.9 \\
4.75\end{array}$ & $\begin{array}{l} \pm \\
\pm\end{array}$ & $\begin{array}{l}0.3 \\
0.7\end{array}$ & 0.07 & 0.79 & 2.23 & 0.14 \\
\hline $\begin{array}{l}\text { Orientation Place } \\
\text { Exercise + Nutrition } \\
\text { Exercise }\end{array}$ & $\begin{array}{l}4.97 \\
4.78\end{array}$ & $\begin{array}{l} \pm \\
\pm\end{array}$ & $\begin{array}{l}0.2 \\
0.5\end{array}$ & $\begin{array}{l}4.9 \\
4.83\end{array}$ & $\begin{array}{l} \pm \\
\pm\end{array}$ & $\begin{array}{l}0.3 \\
0.6\end{array}$ & 0.01 & 0.94 & 0.88 & 0.35 \\
\hline $\begin{array}{l}\text { Registration } \\
\text { Exercise + Nutrition } \\
\text { Exercise }\end{array}$ & $\begin{array}{l}3 \\
2.92\end{array}$ & $\begin{array}{l} \pm \\
\pm\end{array}$ & $\begin{array}{l}0 \\
0.5\end{array}$ & $\begin{array}{l}3 \\
3\end{array}$ & $\begin{array}{l} \pm \\
\pm\end{array}$ & $\begin{array}{l}0 \\
0\end{array}$ & 0.86 & 0.36 & 0.86 & 0.36 \\
\hline $\begin{array}{l}\text { Calculation } \\
\text { Exercise + Nutrition } \\
\text { Exercise }\end{array}$ & $\begin{array}{l}3.84 \\
4.11\end{array}$ & $\begin{array}{l} \pm \\
\pm\end{array}$ & $\begin{array}{l}1.4 \\
1.4\end{array}$ & $\begin{array}{l}4.42 \\
4.14\end{array}$ & $\begin{array}{l} \pm \\
\pm\end{array}$ & $\begin{array}{l}1.2 \\
1.6\end{array}$ & 3.29 & 0.06 & 3.99 & $<0.05 *$ \\
\hline $\begin{array}{l}\text { Recall } \\
\text { Exercise + Nutrition } \\
\text { Exercise }\end{array}$ & $\begin{array}{l}2.88 \\
2.75\end{array}$ & $\begin{array}{l} \pm \\
\pm\end{array}$ & $\begin{array}{l}0.34 \\
0.6\end{array}$ & $\begin{array}{l}2.87 \\
2.61\end{array}$ & $\begin{array}{l} \pm \\
\pm\end{array}$ & $\begin{array}{l}0.43 \\
0.8\end{array}$ & 2.26 & 0.14 & 1.16 & 0.29 \\
\hline $\begin{array}{l}\text { Language and Praxis } \\
\text { Exercise }+ \text { Nutrition } \\
\text { Exercise }\end{array}$ & $\begin{array}{l}8.77 \\
8.7\end{array}$ & $\begin{array}{l} \pm \\
\pm\end{array}$ & $\begin{array}{l}0.5 \\
0.7\end{array}$ & $\begin{array}{l}8.74 \\
8.75\end{array}$ & $\begin{array}{l} \pm \\
\pm\end{array}$ & $\begin{array}{l}0.4 \\
0.55\end{array}$ & 0.02 & 0.88 & 0.31 & 0.58 \\
\hline $\begin{array}{l}\text { Total } \\
\text { Exercise + Nutrition } \\
\text { Exercise }\end{array}$ & $\begin{array}{l}28.26 \\
28.16\end{array}$ & $\begin{array}{l} \pm \\
\pm\end{array}$ & $\begin{array}{l}1.8 \\
2.61\end{array}$ & $\begin{array}{l}28.84 \\
28.08\end{array}$ & $\begin{array}{l} \pm \\
\pm\end{array}$ & $\begin{array}{l}1.44 \\
2.68\end{array}$ & 0.93 & 0.34 & 1.66 & 0.20 \\
\hline
\end{tabular}

Notes: $* \mathrm{P}<0.05$. Bold indicates only one interaction.

that a soy peptide diet suppressed age-related cognitive decline via the upregulation of BDNF in a mouse model with accelerated senescence. ${ }^{26}$ Therefore, we focused on soy peptide as the nutrition of choice combined with multicomponent exercise.

The 3-month soy peptide supplemented with exercise intervention showed a significant effect on calculation function compared with exercise alone. Previous research indicates that exercise and soy peptide intake for 2 weeks in young people improved their computational ability. ${ }^{43}$ In this study, the interaction of time and group for the computational ability was not observed, but the significant beneficial effect for the total score change combined with the recall ability was recognized in soy intake group. Previous research indicates that there is no relationship between typical soy isoflavone intake and the maintenance of cognitive function. ${ }^{44}$ However, in this study, it is speculated that an increase in soy intake compared to typical use concentrated on a three-month period had an effect on calculation improvement.

It has been demonstrated that physical exercise increases BDNF levels. ${ }^{45}$ Thus, the synergistic effect of soy and exercise shown in our study might be due to increased BDNF levels that promote several aspects of brain function. In addition, we predicted a synergistic effect of soy and the multicomponent intervention on physical performance and skeletal muscle mass given that one previous report demonstrates that soy peptide intake after exercising enhances the levels of serum growth hormone involved in muscle synthesis. ${ }^{46}$ However, those synergistic effects were not observed in this study.

The present study has some limitations. First, we did not record the dietary intake of liquids. There may have been changes in dietary intake owing to the consumption of the nutritional supplement. Second, the participants 
were of Japanese nationality and, hence, caution must be exercised while generalizing the study's results to other ethnic groups. Finally, the persistence of the effects of exercise and nutrition remains unclear. Further studies are also needed to measure serum levels of soybean peptide-derived substances in patients to explain the physiological outcomes better. Future interventional trials using soy supplementation in different populations and over longer periods of time have been scheduled.

\section{Conclusions}

In summary, this non-blinded controlled trial showed that participation in a three-month weekly program comprising multicomponent exercise both alone and with the addition of soy peptide supplementation effectively improved a portion of cognitive performance and physical function in elderly adults. A combination of exercise and nutrition may be effective in improving calculation function in such populations.

\section{Research Ethics and Informed Consent}

The Ethics Committee of the Osaka Kawasaki Rehabilitation University (Reference No. OKRU29-A021) approved the trial protocol and the trial was registered at the University Hospital Medical Information Network Clinical Trials Registry (UMIN000030404). Written informed consent for study participation was obtained from all the participants in accordance with the tenets of the Declaration of Helsinki, and no stipend was provided.

\section{Data Sharing Statement}

The datasets available from the corresponding author on reasonable request.

\section{Acknowledgment}

The authors would like to thank Ms Kanako Kodama, Ms Masako Kawano, Ms Saeko Araki, Ms Kaori Hamamura, and senior volunteer staff for their contributions to data collection.

\section{Author Contributions}

All authors contributed to data analysis, drafting and revising the article, gave final approval of the version to be published, and agree to be accountable for all aspects of the work.

\section{Funding}

This work was supported by the Fuji Oil Co., Ltd. and Osaka gas Co., Ltd. The sponsors had no control over the interpretation, writing, or publication of this work.

\section{Disclosure}

M Maebuchi and M Ibuki are employees of Fuji Oil Co. Ltd., which produces Peptide Athleeta 4000. The authors report no other conflicts of interest in this work.

\section{References}

1. Prince M, Guerchet M, Prina M, Alzheimer's Disease International. Policy Brief for Heads of Government: The Global Impact of Dementia 2013-2050. London: Alzheimer's Disease International; 2013. Accessed June 5, 2019.:1-8. Available from: https://www.alz. co.uk/research/GlobalImpactDementia2013.pdf.

2. Prince M, Wimo A, Guerchet M, et al. World Alzheimer Report 2015 : The Global Impact of Dementia: An Analysis of Prevalence, Incidence, Cost and Trends. London: Alzheimer's Disease International; 2015:22-23. Available from: https://www.alz.co.uk/ research/WorldAlzheimerReport2015.pdf. Accessed June 5, 2019.

3. Schuit AJ, Feskens EJ, Launer LJ, Kromhout D. Physical activity and cognitive decline, the role of the apolipoprotein e4 allele. Med Sci Sports Exerc. 2001;33(5):772-777. doi:10.1097/00005768200105000-00015

4. Peila R, White LR, Petrovich H, et al. Joint effect of the APOE gene and midlife systolic blood pressure on late-life cognitive impairment: the Honolulu-Asia aging study. Stroke. 2001;32(12):2882-2889. doi:10.1161/hs 1201.100392

5. Kivipelto M, Helkala EL, Laakso MP, et al. Apolipoprotein E epsilon4 allele, elevated midlife total cholesterol level, and high midlife systolic blood pressure are independent risk factors for late-life Alzheimer disease. Ann Intern Med. 2002;137(3):149-155. doi:10.7326/0003-4819-137-3-200208060-00006

6. Launer LJ, Masaki K, Petrovitch H, Foley D, Havlik RJ. The association between midlife blood pressure levels and late-life cognitive function. The Honolulu-Asia aging study. JAMA. 1995;274 (23):1846-1851. doi:10.1001/jama.1995.03530230032026

7. Takeda S, Sato N, Uchio-Yamada K, et al. Diabetes-accelerated memory dysfunction via cerebrovascular inflammation and abeta deposition in an Alzheimer mouse model with diabetes. Proc Natl Acad Sci U S A. 2010;107(15):7036-7041. doi:10.1073/pnas.10 00645107

8. Tan ZS, Seshadri S, Beiser A, et al. Plasma total cholesterol level as a risk factor for Alzheimer disease: the Framingham study. Arch Intern Med. 2003;163(9):1053-1057. doi:10.1001/archinte.163. 9.1053

9. Dobie DJ. Depression, dementia, and pseudodementia. Semin Clin Neuropsychiatry. 2002;7(3):170-186. doi:10.1053/scnp.2002.007 0170

10. Barnes DE, Yaffe K. The projected effect of risk factor reduction on Alzheimer's disease prevalence. Lancet Neurol. 2011;10(9):819-828. doi:10.1016/S1474-4422(11)70072-2

11. Lang IA, Llewellyn DJ, Langa KM, Wallace RB, Melzer D. Neighbourhood deprivation and incident mobility disability in older adults. Age Ageing. 2008;37(4):403-410. doi:10.1093/ageing/afn092

12. Lang IA, Llewellyn DJ, Langa KM, Wallace RB, Huppert FA, Melzer D. Neighborhood deprivation, individual socioeconomic status, and cognitive function in older people: analyses from the english longitudinal study of ageing. J Am Geriatr Soc. 2008;56(2):191-198. doi:10.1111/(ISSN)1532-5415 
13. Bassuk SS, Glass TA, Berkman LF. Social disengagement and incident cognitive decline in community-dwelling elderly persons. Ann Intern Med. 1999;131(3):165-173. doi:10.7326/0003-4819-1313-199908030-00002

14. Karp A, Kareholt I, Qiu C, Bellander T, Winblad B, Fratiglioni L. Relation of education and occupation-based socioeconomic status to incident Alzheimer's disease. Am J Epidemiol. 2004;159(2):175-183. doi:10.1093/aje/kwh018

15. Verghese J, Lipton RB, Katz MJ, et al. Leisure activities and the risk of dementia in the elderly. $N$ Engl J Med. 2003;348(25):2508-2516. doi:10.1056/NEJMoa022252

16. Gray SL, Hanlon JT, Landerman LR, Artz M, Schmader KE, Fillenbaum GG. Is antioxidant use protective of cognitive function in the community-dwelling elderly? Am J Geriatr Pharmacother. 2003;1(1):3-10. doi:10.1016/S1543-5946(03)80011-9

17. Nicolas A-S, Nourhashemi LF, Lanzmann-Petithory D, Vellas B. Nutrition and cognitive function. Nutr Clin Care. 2001;4 (3):156-167. doi:10.1046/j.1523-5408.2001.00137.x

18. Anstey KJ, Mack HA, Cherbuin N. Alcohol consumption as a risk factor for dementia and cognitive decline: meta-analysis of prospective studies. Am J Geriatr Psychiatry. 2009;17(7):542-555. doi:10.1097/JGP.0b013e3181a2fd07

19. Wilson RS, Mendes De Leon CF, Barnes LL, et al. Participation in cognitively stimulating activities and risk of incident Alzheimer disease. JAMA. 2002;287(6):742-748. doi:10.1001/jama.287.6.742

20. Laurin D, Verreault R, Lindsay J, MacPherson K, Rockwood K. Physical activity and risk of cognitive impairment and dementia in elderly persons. Arch Neurol. 2001;58(3):498-504. doi:10.1001/ archneur.58.3.498

21. Carro E, Trejo JL, Spuch C, Bohl D, Heard JM, Torres-Aleman I. Blockade of the insulin-like growth factor I receptor in the choroid plexus originates Alzheimer's-like neuropathology in rodents: new cues into the human disease? Neurobiol Aging. 2006;27 (11):1618-1631. doi:10.1016/j.neurobiolaging.2005.09.039

22. Aggarwal NT, Wilson RS, Beck TL, Bienias JL, Bennett DA. Motor dysfunction in mild cognitive impairment and the risk of incident Alzheimer disease. Arch Neurol. 2006;63(12):1763-1769. doi:10.1001/archneur.63.12.1763

23. Erickson KI, Voss MW, Prakash RS, et al. Exercise training increases size of hippocampus and improves memory. Proc Natl Acad Sci U S A. 2011;108(7):3017-3022. doi:10.1073/pnas.1015950108

24. Maebuchi MYN, Furuya S. Soy peptide as functional food component. Med Biol. 2011;155:566-576.

25. Maebuchi M, Kishi Y, Koikeda T, Furuya S. Soy peptide dietary supplementation increases serum dopamine level and improves cognitive dysfunction in subjects with mild cognitive impairment. Jpn Pharmacol Ther. 2013;41(1):67-73.

26. Katayama S, Imai R, Sugiyama H, Nakamura S. Oral administration of soy peptides suppresses cognitive decline by induction of neurotrophic factors in SAMP8 mice. J Agric Food Chem. 2014;62 (16):3563-3569. doi:10.1021/jf405416s

27. Folstein MF, Folstein SE, McHugh PR. "Mini-mental state". A practical method for grading the cognitive state of patients for the clinician. J Psychiatr Res. 1975;12(3):189-198. doi:10.1016/ 0022-3956(75)90026-6

28. Tombaugh TN. Trail making test A and B: normative data stratified by age and education. Arch Clin Neuropsychol. 2004;19(2):203-214. doi:10.1016/S0887-6177(03)00039-8

29. Kortte KB, Horner MD, Windham WK. The trail making test, part B: cognitive flexibility or ability to maintain set? Appl Neuropsychol. 2002;9(2):106-109. doi:10.1207/S15324826AN0902_5

30. Nakamura M, Tazaki F, Nomura K, et al. Cognitive impairment associated with locomotive syndrome in community-dwelling elderly women in Japan. Clin Interv Aging. 2017;12:1451-1457. doi:10.2147/ CIA
31. Makizako H, Shimada H, Doi T, et al. Age-dependent changes in physical performance and body composition in community-dwelling Japanese older adults. J Cachexia Sarcopenia Muscle. 2017;8 (4):607-614. doi:10.1002/jcsm.v8.4

32. Shimada H, Suzuki T, Suzukawa M, et al. Performance-based assessments and demand for personal care in older Japanese people: a cross-sectional study. BMJ Open. 2013;3(4):e002424. doi:10.1136/ bmjopen-2012-002424

33. Burke WJ, Roccaforte WH, Wengel SP. The short form of the geriatric depression scale: a comparison with the 30-item form. J Geriatr Psychiatry Neurol. 1991;4(3):173-178. doi:10.1177/ 089198879100400310

34. Ngandu T, Lehtisalo J, Solomon A, et al. A 2 year multidomain intervention of diet, exercise, cognitive training, and vascular risk monitoring versus control to prevent cognitive decline in at-risk elderly people (FINGER): a randomised controlled trial. Lancet. 2015;385(9984):2255-2263. doi:10.1016/S0140-6736(15)60461-5

35. Scherder E, Scherder R, Verburgh L, et al. Executive functions of sedentary elderly may benefit from walking: a systematic review and meta-analysis. Am J Geriatr Psychiatry. 2014;22(8):782-791. doi:10.1016/j.jagp.2012.12.026

36. Miller NH. Compliance with treatment regimens in chronic asymptomatic diseases. Am J Med. 1997;102(2a):43-49. doi:10.1016/S00029343(97)00467-1

37. Doi T, Verghese J, Makizako $\mathrm{H}$, et al. Effects of cognitive leisure activity on cognition in mild cognitive impairment: results of a randomized controlled trial. J Am Med Dir Assoc. 2017;18 (8):686-691. doi:10.1016/j.jamda.2017.02.013

38. Mathai JK, Liu Y, Stein HH. Values for digestible indispensable amino acid scores (DIAAS) for some dairy and plant proteins may better describe protein quality than values calculated using the concept for protein digestibility-corrected amino acid scores (PDCAAS). Br J Nutr. 2017;117(4):490-499. doi:10.1017/S0007114517000125

39. Imai H, Moriyasu K, Nakahata A, Maebuchi M, Ichinose $T$, Furuya S. Soy peptide ingestion augments the synthesis and metabolism of noradrenaline in the mouse brain. Biosci Biotechnol Biochem. 2017;81(5):1007-1013. doi:10.1080/09168451.2017.1282807

40. Nakamoto M, Otsuka R, Nishita Y, et al. Soy food and isoflavone intake reduces the risk of cognitive impairment in elderly Japanese women. Eur J Clin Nutr. 2018;72(10):1458-1462. doi:10.1038/s41430-017-0061-2

41. Moré MI, Freitas U, Rutenberg D. Positive effects of soy lecithinderived phosphatidylserine plus phosphatidic acid on memory, cognition, daily functioning, and mood in elderly patients with Alzheimer's disease and dementia. Adv Ther. 2014;31(12):1247-1262. doi:10.1007/s12325-014-0165-1

42. Lin HC, Peng CH, Huang CN, et al. Soy-based foods are negatively associated with cognitive decline in Taiwan's elderly. J Nutr Sci Vitaminol. 2018;64(5):335-339. doi:10.3177/jnsv.64.335

43. Parker AG, Gordon J, Thornton A, et al. The effects of IQPLUS Focus on cognitive function, mood and endocrine response before and following acute exercise. J Int Soc Sports Nutr. 2011;8(21):16. doi:10.1186/1550-2783-8-16

44. Talaei M, Feng L, Yuan JM, et al. Dairy, soy, and calcium consumption and risk of cognitive impairment: the Singapore Chinese Health Study. Eur J Nutr. 2019. doi:10.1007/s00394-019-02010-8

45. Lev-Vachnish Y, Cadury S, Rotter-Maskowitz A, et al. L-lactate promotes adult hippocampal neurogenesis. Front Neurosci. 2019;13:403. doi:10.3389/fnins.2019.00403

46. Yamada M, Nishiguchi S, Fukutani N, Aoyama T, Arai H. Mailbased intervention for sarcopenia prevention increased anabolic hormone and skeletal muscle mass in community-dwelling japanese older adults: the INE (Intervention by Nutrition and Exercise) study. J Am Med Dir Assoc. 2015;16(8):654-660. doi:10.1016/j. jamda.2015.02.017 


\section{Publish your work in this journal}

Clinical Interventions in Aging is an international, peer-reviewed journal focusing on evidence-based reports on the value or lack thereof of treatments intended to prevent or delay the onset of maladaptive correlates of aging in human beings. This journal is indexed on PubMed Central, MedLine, CAS, Scopus and the Elsevier
Bibliographic databases. The manuscript management system is completely online and includes a very quick and fair peer-review system, which is all easy to use. Visit http://www.dovepress.com/ testimonials.php to read real quotes from published authors.

Submit your manuscript here: https://www.dovepress.com/clinical-interventions-in-aging-journal 